\title{
Management of Vegetation by Alternative Practices in Fields and Roadsides
}

\author{
Allen V. Barker and Randall G. Prostak \\ Department of Plant, Soil, and Insect Sciences, University of Massachusetts, Amherst, MA 01003, USA \\ Correspondence should be addressed to Allen V. Barker; barker@pssci.umass.edu
}

Received 16 January 2014; Revised 24 June 2014; Accepted 4 July 2014; Published 24 August 2014

Academic Editor: Robert J. Kremer

Copyright (C) 2014 A. V. Barker and R. G. Prostak. This is an open access article distributed under the Creative Commons Attribution License, which permits unrestricted use, distribution, and reproduction in any medium, provided the original work is properly cited.

\begin{abstract}
In attempts to reduce the amounts of conventional herbicides used, alternative practices are sought in the management of roadside vegetation. In this investigation, alternative herbicides (citric-acetic acids, clove oil, corn gluten meal, limonene, and pelargonic acid), flaming, and mulching were assessed in management of annual and perennial, herbaceous vegetation in field and roadside plots. Several formulations of alternative herbicides applied singly or repeatedly during the growing season were evaluated and compared with conventional herbicides (glyphosate and glufosinate ammonium) or with flaming or mulching. Citric-acetic acid formulations, clove oil, limonene, or pelargonic acid applied as foliar sprays immediately desiccated foliage, but the efficacy lasted for no longer than five weeks. Repeated applications were better than single applications of these herbicides in suppressing plant vegetative growth. Corn gluten meal imparted little or no early control and stimulated late-season growth of vegetation. A single flaming of vegetation gave no better control than the alternative herbicides, but repeated flaming strongly restricted growth. Mulching with wood chips or bark gave season-long suppression of vegetation. Glyphosate gave season-long inhibition of vegetation, but the efficacy of glufosinate ammonium waned as the growing season progressed. For season-long suppression of vegetation with alternative herbicides or flaming repeated applications will be required.
\end{abstract}

\section{Introduction}

Management of vegetation is an important element for safety and aesthetics in healthy roadside environments. Methods of management to produce this environment include cultural, biological, mechanical, and chemical procedures for weed control. Mechanical methods, primarily mowing, are the most widely used methods [1]. Chemical control involving the use of herbicides is used substantially in management of roadside vegetation [1].

Use of herbicides provides flexibility and low costs in control of vegetation, considering the equipment and the wide spectrum of materials that are available for use [1]. However, some of the public does not believe that commonly used herbicides are safe for use along roadsides [2]. Consequently, state departments of transportation are investigating alternatives to conventional herbicides in weed management. Alternatives include chemical treatments with plant-derived herbicides and mechanical treatments. Several alternative herbicides that are marketed as products to manage growth of vegetation have an active ingredient that is of plant origin or include various by-products of food and feed processing $[3,4]$.

Corn gluten meal (CGM) is the proteinaceous by-product from the milling of corn grain to make cornstarch and corn syrup and is about $60 \%$ protein or about $10 \%$ nitrogen by weight [5]. Peptides in the material impart preemergence herbicidal activity by inhibiting root growth from germinating seeds in soil $[6,7]$. Corn gluten meal is nonselective, and banded application for row-crop production was recommended over broadcast application to avoid yield suppression of crops [8]. Corn gluten meal also can fertilize crops or weeds and may thereby improve crop growth or increase weed competition $[9,10]$.

Acetic acid and citric acid [11-19] are alterative materials that work as nonselective, postemergence, contact herbicides causing rapid desiccation of plant foliage. Their use as herbicides involves application as a foliar spray at concentrations 
ranging from 10 to $20 \%$ (v:v) acetic acid, citric acid, or blends of the two on weeds that are about 6 to 9 inches tall or less [16]. As growth stage advances, control and biomass suppression decreases and survival increases [12, 18]. Generally, 80 to $100 \%$ kill rates can be expected for small annual and perennial weeds, but perennial species with persistent root systems will regrow within several weeks. Repeated applications are needed to control large annual and perennial weeds and plants that grow from newly emerged seedlings $[1,19]$. Reports noted that acetic acid or citric was nonselective and that crop damage and yield suppression would occur if these herbicides came in contact with the crops $[13,14]$.

Pelargonic acid (nonanoic acid) is a naturally occurring fatty acid in the oil of geranium (Pelargonium spp. L'Her.) $[20,21]$. The commercial product is manufactured from other fatty acids and is a nonselective, contact herbicide, which effectively controls annual broadleaf and grass weeds that are less than 6 inches high [22]. Repeated applications may be required with large annual plants and perennials. Pelargonic acid has been investigated also as a preharvest desiccant [23]. Research on use along highways is not evident, but uses in the other applications indicate that this material could be used for weed control on roadsides.

Clove oil, derived from the clove plant (Syzygium aromaticum Merr. and Perry), is active against various organisms including nematodes [24], insects [25], microorganisms [26$28]$, and plants $[4,29,30]$ and may have potential as a postemergence desiccant in roadside environments. Brainard et al. [11] reported that a concentration of at least $7.5 \%(\mathrm{v} / \mathrm{v})$ of clove oil was needed for control of annual broadleaf weeds but that poor control of annual grasses was achieved.

Limonene is a cyclic terpene derived from oil of the rind of citrus fruits [21]. It has common uses as a cleaner or degreaser in household and industrial uses and as an adjuvant to increase the penetration of agricultural chemical into plant leaves. Limonene also has insecticidal and antimicrobial activities [31-35]. The phytotoxic response of some plants to limonene suggests that it has herbicidal properties [36]. Limonene has not been evaluated for herbicidal activity in roadside environments.

Burning of fields to reduce weed populations has been a historic practice but has many disadvantages including air pollution, reduced visibility caused by smoke, and the chance of uncontrolled fire. Burner-type weeders deliver heat energy to the plants directly by close contact to a flame. Ascard [37, 38] and Rifai et al. [39] reported that weeds with thin leaves and unprotected growing points were more susceptible to flaming than grasses and other species with protected growing points. All species were most susceptible to flaming when small (0-4 true leaves) compared to larger plants (6-12 true leaves), and significantly more heat energy was needed to control the larger plants.

Covering the soil with a mulch of a layer of organic matter or with a barrier, such as plastic or landscape fabric, has potential use in roadside weed control in small areas, such as around sign posts, along fence rows, and under guardrails. The weed-control function of mulches is based on the blocking of sunlight from the plants or on the presentation of a barrier through which the weeds cannot emerge $[40,41]$. Some preparation of land, such as shallow cultivation, is necessary to reduce early weed competition for organic mulches such as wood chips to be effective in weed control [42].

In field and roadside plots, this research investigated the use of corn gluten meal, acetic-citric acid formulations, pelargonic acid, clove oil, limonene, flaming, and mulches as alternative practices for management of vegetation. These practices were compared with use of conventional herbicides of glyphosate and glufosinate ammonium. Mowing of vegetation also was investigated for its effects on the efficacy of alternative herbicides.

\section{Materials and Methods}

Two studies were conducted. This work was part of an investigation in which several alternative methods of weed control on roadsides were evaluated [1]. One study involved experiments in field plots at a University of Massachusetts research farm in South Deerfield, and the other involved experiments on curbsides of a driveway and parking area at a weigh station along Interstate 91 in Deerfield, Massachusetts.

2.1. Field Plot Research. This research was conducted in 2005 to gain information on the efficacy of alternative herbicides and mechanical treatments. Field plot experimentation allowed for research on land with more uniform stands of vegetation than those that existed along roadsides.

\subsubsection{Evaluation of Conventional and Alternative Herbicides} and Mechanical Treatments for Control of Vegetation in Field Plots. Two experiments were conducted. Experiment 1 investigated the efficacy of various alternative herbicides applied at different amounts, mechanical treatments, and conventional herbicides (Table 1). Experiment 2 investigated the effects of repeated applications of alternative practices (Table 2). These experiments were conducted in plots on two side-by-side areas of land at the South Deerfield farm of the University of Massachusetts. One area was infested with annual grasses crabgrass, Digitaria spp. Haller; foxtail (Setaria glauca Roem. and Schult); and annual broadleaf species (lambsquarters, Chenopodium album L.; marestail, Conyza canadensis Cronquist; redroot pigweed, Amaranthus retroflexus L.), a situation that was created by tillage of the land in the spring of the year of research. The other area was infested mainly with perennial grasses, almost entirely quackgrass (Agropyron repens Beauv.) in untilled land. Each area received all of the treatments described in the next paragraphs. Plot size was $1.2 \mathrm{~m}$ by $4.6 \mathrm{~m}$, and the experimental design was a randomized, complete block with three replications in each experiment.

Field Experiment 1. Alternative herbicides (clove oil, pelargonic acid, citric-acetic acid, and corn gluten meal) were applied in different amounts (Table 1). These applications were developed from the label recommendations and from preliminary research in a greenhouse [1]. Also, included in the experiment was the evaluation of flaming with a handheld torch (500,000 BTU, Red Dragon, Flame Engineering, Inc., 
TABLE 1: Treatments in experiments involving alternative herbicides applied in differing amounts, conventional herbicides, and mechanical treatments in field plot research (Field Experiment 1).

\begin{tabular}{|c|c|}
\hline Alternative practice & Application \\
\hline Herbicide $^{\dagger}$ & Active ingredient, $\mathrm{L} \mathrm{ha}^{-1}$ \\
\hline Untreated & 0 \\
\hline Clove oil & 34 \\
\hline “ & 68 \\
\hline “ & 102 \\
\hline Pelargonic acid & 13 \\
\hline “ & 26 \\
\hline “ & 39 \\
\hline Citric-acetic acid & 34 \\
\hline Citric acid & 45 \\
\hline Glyphosate & 2.8 \\
\hline Glufosinate ammonium & 1.8 \\
\hline Corn gluten meal & $975 \mathrm{~kg} \mathrm{ha}^{-1}$ \\
\hline “ & $2,925 \mathrm{~kg} \mathrm{ha}^{-1}$ \\
\hline “ & $4,875 \mathrm{~kg} \mathrm{ha}^{-1}$ \\
\hline \multicolumn{2}{|l|}{ Mechanical treatments } \\
\hline Flaming & Vegetation ashed \\
\hline Bark mulch & $760 \mathrm{~m}^{3} \mathrm{ha}^{-1}$ \\
\hline Woodchips mulch & $760 \mathrm{~m}^{3} \mathrm{ha}^{-1}$ \\
\hline \multicolumn{2}{|c|}{$\begin{array}{l}{ }^{\dagger} \text { Clove oil, Matran EC, } 500 \mathrm{~mL} / \mathrm{L} \text { a.i., EcoSMART Technologies, Franklin, } \\
\text { TN; pelargonic acid, Scythe, } 570 \mathrm{~mL} \text { a.i./L., Mycogen Corporation, San } \\
\text { Diego; citric-acetic acid, Ground Force, } 50 \mathrm{~mL} \text { citric acid/L, acetic acid } \\
\text { unspecified, Abby Laboratories, Ramsey, MN; citric acid, Brush and Black- } \\
\text { berry Block, } 200 \mathrm{~mL} \text { a.i./L, Greenergy, Brookings, OR; glyphosate, Roundup } \\
\text { Pro, } 410 \mathrm{~mL} \text { a.i./L, Monsanto Company, St. Louis, MO; glufosinate ammo- } \\
\text { nium, Finale, } 200 \mathrm{~mL} \text { a.i./L, Bayer Environmental Science, Montcalm, NJ; } \\
\text { and corn gluten meal, about } 600 \mathrm{~g} \text { crude protein } / \mathrm{kg} \text {, applied to surface after } \\
\text { flaming vegetation by torch; tabulated application is total product. }\end{array}$} \\
\hline $\begin{array}{l}\text { } \text { Flaming with propane-firec } \\
\text { mulch, mixed tree-bark mul } \\
\text { woodchips, } 7.5 \mathrm{~cm} \text { thick follo }\end{array}$ & $\begin{array}{l}\text { getation to soil surface; bark } \\
\text { voodchips mulch, mixed tree }\end{array}$ \\
\hline
\end{tabular}

TABLE 2: Treatments involved in repeated applications of alternative herbicides or flaming in field plot experiments (Field Experiment 2).

\begin{tabular}{lc}
\hline Treatment & Application, active ingredient, $\mathrm{L} \mathrm{ha}^{-1^{\dagger}}$ \\
\hline Clove oil & 34 \\
Pelargonic acid & 13 \\
Citric acid-acetic acid & 34 \\
Citric acid & 45 \\
Flaming & ${ }^{\ddagger}$ Ashing of vegetation
\end{tabular}

${ }^{\dagger}$ Applications occurred in July, July and August, and July, August, and September (see Table 1 for identity of herbicides).

${ }^{\ddagger}$ Vegetation was ashed to ground surface on the three dates noted above for applications.

LaCrosse, KS) and mulching with 3-inch layers of hardwood bark or woodchips. Flaming to ash vegetation was used to prepare plots for mulching and for application of corn gluten meal. Treatments with conventional herbicides, glyphosate and glufosinate ammonium (Table 1), were included in the trial. Plots were treated on July 20, 2005, with alternative or conventional herbicides, mulching, or flaming and were
TABLE 3: Visual indexing for scoring efficacy of treatments.

\begin{tabular}{ll}
\hline Index score & Description of score \\
\hline 0 & No control of vegetation \\
1 & Less than $10 \%$ of vegetation controlled \\
2 & Between 11 and $20 \%$ of vegetation controlled \\
3 & Between 21 and $30 \%$ of vegetation controlled \\
4 & Between 31 and $40 \%$ of vegetation controlled \\
5 & Between 41 and $50 \%$ of vegetation controlled \\
6 & Between 51 and $60 \%$ of vegetation controlled \\
7 & Between 61 and $70 \%$ of vegetation controlled \\
8 & Between 71 and $80 \%$ of vegetation controlled \\
9 & Between 81 and $90 \%$ of vegetation controlled \\
9.5 & $\begin{array}{l}\text { A rating used when more than } 90 \% \text { of the vegetation } \\
\text { was controlled with only one or two live plants } \\
\text { remaining in a plot. } \\
10\end{array}$ \\
& $\begin{array}{l}\text { This rating was applied when all of the vegetation } \\
\text { was killed or if no regrowth occurred at the time of } \\
\text { rating. }\end{array}$ \\
\hline
\end{tabular}

evaluated on August 1, September 9, and September 23, 2005 , by visual indexing (Table 3 ) and in the following year without indexing. In the second year, the flamed and herbicide-treated plots were overgrown with the original week mass, and the mulched plots had sparse emergence of dandelion (Taraxacum officinale F. H. Wigg) and milkweed (Asclepias syriaca L.). In the first year, mass of shoot growth was determined by weighing $0.25 \mathrm{~m}^{2}$ of the vegetation cut to ground level after the final visual rating.

Field Experiment 2. Another experiment was conducted at the same time and in the same areas as described above. In the second experiment, several alternative herbicides were evaluated with different times of repeated applications (Table 2). Treatments of alternative herbicides or flaming were applied on July 21, August 15, and September 9, 2005. Some plots received the treatments only in July; some received the treatments in July and August, and some received the treatments in July, August, and September. Mulching and conventional herbicides were not included in this experiment. Treatments were evaluated on August 1, September 9, and September 23, 2005, by visual indexing (Table 3), and mass of shoot growth was determined by weighing $0.25 \mathrm{~m}^{2}$ of the vegetation cut at ground level on September 28. The plots also were evaluated in the spring of 2006.

2.2. Roadside Research. This research involved two experiments in 2006 run simultaneously with alternative herbicides at curbsides along driveways at a weighing station along Interstate 91 in South Deerfield, Massachusetts. In one experiment, alternative herbicides of clove oil, pelargonic acid, and limonene were applied in two amounts (Table 4). In the second experiment, the lower amounts of these herbicides were used, and a citric acid-acetic acid based material and a conventional herbicide (glyphosate) were additional treatments (Table 4). The principal species was tall fescue 
TABLE 4: Treatments employed in two experiments in roadside research with alternative herbicides (Roadside Experiments).

\begin{tabular}{|c|c|c|c|}
\hline \multicolumn{2}{|c|}{ Experiment 1} & \multicolumn{2}{|c|}{ Experiment 2} \\
\hline Material $^{\dagger}$ & Application, active ingredient, $\mathrm{L} \mathrm{ha}^{-1}$ & Material $^{\dagger}$ & Application, active ingredient, $\mathrm{L} \mathrm{ha}^{-1}$ \\
\hline \multirow{2}{*}{$\begin{array}{l}\text { Clove oil } \\
\text { “ }\end{array}$} & 34 & \multirow{2}{*}{ Clove oil } & \multirow{2}{*}{34} \\
\hline & 68 & & \\
\hline \multirow{2}{*}{$\begin{array}{l}\text { Pelargonic acid } \\
\text { “ }\end{array}$} & 13 & \multirow{2}{*}{ Pelargonic acid } & \multirow{2}{*}{13} \\
\hline & 26 & & \\
\hline \multirow{2}{*}{$\begin{array}{l}\text { Limonene } \\
\text { “ }\end{array}$} & 18 & \multirow{2}{*}{ Limonene } & \multirow{2}{*}{18} \\
\hline & 36 & & \\
\hline \multirow[t]{6}{*}{ Untreated } & 0 & Clove oil & 34 \\
\hline & & and limonene & 18 \\
\hline & & Citric acid- & 25 \\
\hline & & acetic acid & 19 \\
\hline & & Glyphosate & 2.8 \\
\hline & & Untreated & 0 \\
\hline
\end{tabular}

${ }^{\dagger}$ Clove oil, Matran EC, 500 mL a.i./L., EcoSMART Technologies, Franklin, TN; limonene, Natures Avenger, 175 mL a.i./L, Cutting Edge Formulations, Buford, GA; pelargonic acid, Scythe, $570 \mathrm{~mL}$ a.i./L, Mycogen Corporation, San Diego; citric acid-acetic acid, AllDown, $80 \mathrm{~mL}$ citric acid/L and $60 \mathrm{~mL}$ acetic acid/L, Summerset Products, Chaska, MN; and glyphosate, Roundup Pro, $410 \mathrm{~mL}$ a.i./L, Monsanto Company, St. Louis, MO.

(Festuca arundinacea Schreb.). The experimental design was split plot with half of a block being mowed to $10 \mathrm{~cm}$ heights with a string mower and with half of the block remaining unmowed. The vegetation was about $20 \mathrm{~cm}$ high at mowing. Mowing was on July 3, 2006, and treatments were applied on July 6, 2006, in a randomized, complete block design within the split plots and with three replications. Plot size was $1.2 \mathrm{~m}$ by $4.6 \mathrm{~m}$ along on the shoulders. Control of growth of vegetation (Table 3) was assessed at weekly or biweekly intervals after application of the treatments. On September 28 , the mass of shoot growth was determined by cutting plants at ground level from $0.25 \mathrm{~m}^{2}$ of plot.

2.3. Statistical Procedures. Data were processed by analysis of variance employing statistical software (SAS Institute, Cary, NC), and means were separated by $F$-test or by least significant difference (LSD, $P=0.05)$ [43].

\section{Results}

\subsection{Field Plot Research}

\subsubsection{Effects of Applications of Conventional Herbicides and Alternative Herbicides and Effects of Mechanical Treatments on Control of Annual and Perennial Vegetation}

Field Experiment 1 (effects of different amounts of alternative herbicides and mechanical treatments on management of vegetation). No differences in efficacy in weed management among amounts of application of alternative herbicides occurred at the first two ratings of the field plots (August 1 and September 9); hence, means of the various rates are reported (Table 5). The effects of the two citric acid-based herbicides (Ground Force or Brush and Blackberry Block, Table 1) or the two mulches (bark or woodchip) were not different and are included as means in the table. The effects of treatments at the end of the experiment (September 23) are reported in Table 6 , which gives the visual indices and the mass of the plants. Averages of treatments in Table 6 are reported as described in Table 5 .

Annual Weeds. For plots infested with annual vegetation, the visual indexing indicated that about 10 days (August 1) after application of treatments, the citric acid-based treatments gave little suppression of annual vegetation and that the clove oil and pelargonic acid gave weak to moderate control (Table 5). Flaming or application of the two conventional herbicides (glyphosate or glufosinate ammonium) gave full control of annual vegetation at this time. As the season progressed to about 6 weeks after treatment (September 9), suppression of annual vegetation from burning or application of glyphosate or glufosinate ammonium persisted, but the alternative herbicides had few suppressing effects on vegetation. At 6 weeks, plant growth from seeds or from surviving crowns of plants in the soil gave return of vegetation to the plots that were flamed. The conventional herbicides (glyphosate and glufosinate ammonium) fully controlled the annual vegetation at the September 9 date of assessment.

In August, the benefits of the corn gluten meal in the suppression of annual weeds may be due to flaming before application of the meal. The meal stimulated growth of vegetation relative to the growth with flaming alone as is indicated by the lesser suppression with the meal than with flaming alone in the September 9 rating. Mulch applied after flaming suppressed weeds through the September 9 date of evaluation. No visual differences were noted between bark mulch and woodchip mulch; hence, the ratings of these plots are pooled into one entry. No weeds were emerging through either of the mulching materials, whereas, with the flaming alone, weeds were reappearing in the plots.

The end-of-season visual indexing (September 23) indicated that the efficacy of all alternative, sprayed herbicides 
TABLE 5: Assessments of conventional and alternative herbicides and mechanical treatments on early season control of vegetation in field plots with annual and perennial vegetation (Field Experiment 1).

\begin{tabular}{|c|c|c|c|c|}
\hline \multirow{4}{*}{ Treatment } & \multicolumn{4}{|c|}{ Rating and type of vegetation and date ${ }^{\dagger}$} \\
\hline & \multicolumn{2}{|c|}{ August 1} & \multicolumn{2}{|c|}{ September 9} \\
\hline & Annual & Perennial & Annual & Perennial \\
\hline & \multicolumn{4}{|c|}{ Visual index ${ }^{\ddagger}$} \\
\hline None & 0 & 0 & 0 & 0 \\
\hline Clove oil ${ }^{\S}$ & 2.6 & 4.1 & 0.7 & 0.7 \\
\hline Pelargonic acid ${ }^{\S}$ & 4.8 & 4.1 & 0.7 & 0.7 \\
\hline Citric acid" & 0.5 & 2.4 & 0 & 0.4 \\
\hline Corn gluten meal ${ }^{\S}$ & 9.7 & 8.5 & 4.7 & 3.2 \\
\hline Flaming & 10.0 & 8.0 & 7.8 & 5.0 \\
\hline Mulches & 10.0 & 10.0 & 9.0 & 9.2 \\
\hline Glyphosate & 10.0 & 10.0 & 8.8 & 7.0 \\
\hline Glufosinate ammonium & 10.0 & 10.0 & 8.5 & 1.0 \\
\hline $\operatorname{LSD}(P=0.05)$ & 1.0 & 1.6 & 1.3 & 1.0 \\
\hline
\end{tabular}

${ }^{\dagger}$ Treatments applied on July 20, 2005. See Table 1.

${ }^{\ddagger}$ Visual rating index of efficacy of materials; see Table 3.

${ }^{\S}$ Means of 3 rates of alternative herbicides; effects of rates of application were nonsignificant.

Including means of two citric acid based herbicides, the effects of which were not significantly different. Bark mulch or woodchips mulch did not differ in effects, and means of the two mulches are tabulated.

TABLE 6: End-of-season weed mass and visual indexing of treatments with alternative herbicides, mulches, burning, or conventional herbicides in field plot research with annual and perennial vegetation (Field Experiment 1).

\begin{tabular}{|c|c|c|c|c|}
\hline \multirow{2}{*}{ Treatment $^{\dagger}$} & \multicolumn{2}{|c|}{ Weed mass, $\mathrm{g}$ fresh $\mathrm{wt} \mathrm{m}^{-2^{\ddagger}}$} & \multicolumn{2}{|c|}{ Visual index rating ${ }^{\S}$} \\
\hline & Annual & Perennial & Annual & Perennial \\
\hline Untreated & 2,910 & 1,574 & 0 & 0 \\
\hline Clove oil & 2,332 & 954 & 0.2 & 0.2 \\
\hline Pelargonic acid & 2,360 & 774 & 0.3 & 0.3 \\
\hline Citric acid & 2,340 & 808 & 0.5 & 0.4 \\
\hline Corn gluten meal & 1,743 & 1,350 & 3.2 & 3.1 \\
\hline Mulch & 32 & 208 & 9.3 & 9.3 \\
\hline Flaming & 1,486 & 384 & 5.0 & 5.0 \\
\hline Glyphosate & 638 & 741 & 7.0 & 7.0 \\
\hline Glufosinate ammonium & 854 & 644 & 1.0 & 1.0 \\
\hline $\operatorname{LSD}(P=0.05)$ & 1,164 & 472 & 1.4 & 1.1 \\
\hline
\end{tabular}

${ }^{\dagger}$ All treatments were applied on July 20 and July 21, 2005. Amounts of alternative herbicides, sources of citric acid, or kind of mulch had no significant effect on efficacy; hence, means of the applications are reported. See Table 1 for presentation of treatments.

${ }^{\ddagger}$ Weed fresh mass was measured on September 28, 2005.

${ }^{\S}$ Visual rating index on September 23, 2005. See Table 3.

and glufosinate ammonium had waned to $10 \%$ or less control of vegetation (Table 3, Table 6). The different amounts of alternative herbicides applied had no effect on growth or indexing, and results are combined for tabulation. Glyphosate continued to provide strong efficacy for weed control until the end of the experiment. Increased amounts of application of corn gluten meal did not improve its efficacy; hence, means of all rates of the meal are reported. Based on visual indexing, corn gluten meal following flaming gave somewhat better control than the alternative herbicides. Also, based on visual indexing or shoot mass, corn gluten meal, which was applied to flamed plots, had lower efficacy than flaming alone, indicating that the corn gluten meal had a stimulatory effect on weed growth, likely through its action as a nitrogen fertilizer. The shoot mass of weeds in the flamed plots was about half of that in the untreated plots, whereas the average mass of vegetation from the plots treated with corn gluten meal following burning was about $60 \%$ of the untreated plot biomass. At the end of the growing season, the treatments with corn gluten meal kept the weeds green and sustained growth, whereas the plants in the other treatments were senescing.

The pelargonic acid herbicide had high efficacy in initial killing of annual vegetation, but this efficacy dissipated during the growing season as the surviving roots and crowns of the plants recovered from the initial dieback and emerging seedlings grew to produce shoot biomass that was not different from that of the untreated plots or of the clove 
oil, citric acid, or corn gluten meal treatments. Glyphosate or glufosinate ammonium restricted weed mass more than the alternative treatments except flaming or mulching. The mulches gave the best season-long control of vegetation of all of the treatments employed in this experiment.

Perennial Weeds. In August (10 days after treatment), the citric acid-acetic acid treatments gave only a slight growth suppression of perennial weeds, which were almost all quackgrass (Table 3, Table 5). No suppression by these treatments was evident on September 9, about 6 weeks after application. The clove oil or pelargonic acid treatment showed some suppression in August, but this control also had abated by the early September date. After giving growth suppression at the August rating, the efficacy of glufosinate ammonium was lost by September 9. Glyphosate was effective in control of perennial vegetation on both dates. In the plots cleared of vegetation by flaming, annual and perennial weeds were emerging in the plots initially dominated by the perennial vegetation, but the control remained moderately effective through early September. Few weeds were emerging through the mulches on any date. Corn gluten meal gave only weak suppression of vegetation at the early September date and was not as effective as flaming alone even though the plots with corn gluten meal had been preburned.

Generally, the plots treated with alternative, sprayed herbicides had smaller end-of-season (September 28) (Table 6) biomasses than untreated plots, but visual indexing did not make this distinction, suggesting that the aesthetics of the plots treated with alternative herbicides was not better than no treatment. The mass of weeds in the plots treated with corn gluten meal did not differ from that of the untreated plots, although visual indexing suggested some control from the meal. The visual rating may have assessed a sparser population of larger plants in the plots treated with corn gluten meal than in the untreated plots.

Glyphosate gave strong suppression of weed growth at the end of the season. Based on visual indexing, glufosinate ammonium had little efficacy in season-long control of weeds, indicating that the early season control had dissipated. Also, the mass of vegetation did not differ from many of the treatments with alternative herbicides, although the mass of weeds in plots treated with glufosinate ammonium was less than that from the untreated plots.

Plots flamed with a weed torch had weed masses that were about $20 \%$ of the end-of-season growth of the untreated perennial weed plots (Table 6). Flamed plots also had higher weed suppression indexes than the untreated plots or plots treated with alternative herbicides.

Mulching with wood chips or bark chips had strong suppressive effects on perennial vegetation at the end of the season, continuing the early season suppression that was noted. Suppression of weed mass was greater with the mulches than with any other treatment.

With either the annual weeds or the perennial weeds, visual observations in the spring of the following year showed that only the mulched plots had a residual effect on weed control. In these plots, milkweed and dandelion were growing sparse populations. All of the other treatments showed no residual control and were not distinguishable from the treatment of no herbicide applied in the previous season.

Field Experiment 2 (effects of repeated applications of alternative treatments on control of vegetation). This experiment was conducted at the same time and site as Experiment 1. Treatments of alternative herbicides or flaming were applied in July, August, and September. One-third of the plots received the treatments only in July; one-third received the treatments in July and August, and one-third received the treatments in July, August, and September (Table 2). Mulching and conventional herbicides were not included in this experiment.

Annual and Perennial Weeds. Immediately after application of the treatments, vegetation treated with clove oil, pelargonic acid, or either of citric-acid based materials showed wilting and burning of foliage. At 10 days (August 1) and at 6 weeks (September 9) after treatment applications, the efficacies of the one-time applications were assessed (Table 7). The effects of the citric-acetic acid herbicide and the citric acid herbicide differed, and the results of these materials are reported separately. The alternative herbicides had only weakly suppressive effects on growth of vegetation, and the effects diminished as time after treatment advanced from 10 days to 6 weeks. These materials are contact herbicides, which kill the foliage that is exposed to contact but which do not damage the entire plant so that perennials resumed growth. Also, some of the returning growth was from newly emerged plants, especially in the plots with annual weeds. Flaming had much better short-term effects on suppression of vegetation than the alternative herbicides, but the effects of flaming also diminished with time, as a result of emergence of new plants from the soil and regrowth from roots and crowns.

Suppression in weed mass indicates that increasing the number of applications of alternative herbicides increased the control of weeds (Table 8). However, visual indexing, based on observations of the appearance of the plot of vegetative coverage of the plots, suggested that the multiple treatments of the alternative herbicides were not effective on the aesthetics of the plots at the end of the season. Each flaming eliminated all aboveground vegetation so that the multiple treatments with fire gave good end of the season control of weeds.

Based on weed masses, pelargonic acid or flaming gave the best control of annual or perennial weeds (Table 9). Based on weed mass, the citric acid or clove oil treatments were better than no application of herbicide with annual or perennial vegetation. Judging of the plants by visual indexing suggested that only the flaming treatment was better than no treatment with the annual species and that all treatments were better than no treatment with the perennial species.

\subsection{Roadside Research}

Roadside Experiment 1 (clove oil, pelargonic acid, and limonene applied at two concentrations to mowed or unmowed plots). Mowing of the plots did not increase the efficacy of the herbicides, as no differences occurred between mowing 
TABLE 7: Efficacy of alternative herbicides and burning of vegetation at ten days and six weeks after one application of treatments in field plot experiment with repeated applications on annual and perennial vegetation (Field Experiment 2).

\begin{tabular}{|c|c|c|c|c|}
\hline \multirow{4}{*}{ Treatment $^{\dagger}$} & \multicolumn{4}{|c|}{ Rating by date and type of vegetation } \\
\hline & \multicolumn{2}{|c|}{ August 1} & \multicolumn{2}{|c|}{ September 9} \\
\hline & Annual & Perennial & Annual & Perennial \\
\hline & \multicolumn{4}{|c|}{ Visual index ${ }^{\ddagger}$} \\
\hline Clove oil & 1.7 & 0.9 & 0 & 1.0 \\
\hline Pelargonic acid & 3.3 & 7.3 & 0.7 & 1.4 \\
\hline Citric-acetic acid ${ }^{\S}$ & 2.7 & 4.7 & 0.7 & 1.2 \\
\hline Citric acid ${ }^{\S}$ & 0.3 & 0.7 & 0 & 0.5 \\
\hline Flaming & 9.5 & 8.7 & 4.7 & 2.7 \\
\hline $\operatorname{LSD}(P=0.05)$ & 1.0 & 1.0 & 1.3 & 1.3 \\
\hline
\end{tabular}

${ }^{\dagger}$ One application of the herbicides or burning was made on July 21, 2005.

${ }^{\ddagger}$ Visual index. See Table 3 for indexing scale.

${ }^{\S}$ Citric-acetic acid was Ground Force; citric acid was Brush and Black Berry Block. See Table 1.

TABLE 8: End-of-season mass of shoots of weeds and ratings of efficacy of treatments with repeated applications of alternative practices in field plot research with annual and perennial vegetation (Field Experiment 2).

\begin{tabular}{|c|c|c|c|c|c|}
\hline \multirow{4}{*}{$\begin{array}{l}\text { Treatment } \\
\text { Clove oil }\end{array}$} & \multirow{2}{*}{$\frac{\text { Times repeated }^{\dagger}}{1}$} & \multicolumn{2}{|c|}{ Weed mass, $\mathrm{g}$ fresh wt $\mathrm{m}^{-2^{\ddagger}}$} & \multicolumn{2}{|c|}{ Visual index rating $^{\S}$} \\
\hline & & 2,174 & 860 & 0.3 & 1.0 \\
\hline & 2 & 1,226 & 708 & 0.3 & 1.0 \\
\hline & 3 & 496 & 415 & 0.3 & 1.0 \\
\hline \multirow{3}{*}{ Pelargonic acid } & 1 & 1,241 & 546 & 0.7 & 1.7 \\
\hline & 2 & 1,128 & 353 & 1.3 & 1.3 \\
\hline & 3 & 474 & 241 & 1.3 & 1.3 \\
\hline \multirow{3}{*}{ Citric acid-acetic acid } & 1 & 2,037 & 875 & 0.7 & 1.0 \\
\hline & 2 & 924 & 776 & 1.3 & 1.3 \\
\hline & 3 & 827 & 394 & 1.0 & 1.3 \\
\hline \multirow{3}{*}{ Citric acid } & 1 & 1,960 & 686 & 0 & 0 \\
\hline & 2 & 1,779 & 753 & 0 & 1.0 \\
\hline & 3 & 1,954 & 717 & 0 & 0.7 \\
\hline \multirow{3}{*}{ Flaming } & 1 & 1,046 & 381 & 4.7 & 4.0 \\
\hline & 2 & 453 & 336 & 9.5 & 4.3 \\
\hline & 3 & 150 & 90 & 9.5 & 4.7 \\
\hline $\operatorname{LSD}(P=0.05)$ & & 611 & 234 & 1.0 & 1.0 \\
\hline
\end{tabular}

${ }^{\dagger}$ 1, first application, July 21; 2, second application, August 15; and 3, third application, September 9, 2005.

${ }^{\ddagger}$ Fresh mass on September 28, 2005.

${ }^{\S}$ Visual rating index on September 23, 2005. See Table 3 for indexing scale.

treatments or between the interaction of mowing with herbicides or with date of observation (Table 3, Table 10). In fact, in the short term (1 week), the efficacy on the unmowed plots (mean index rating 5.6 on the 10 -point scale) was slightly larger than with the mowed plots (4.6 rating), and the mean of all season-long ratings showed a similar relationship with the unmowed mean being 3.3 and the mowed mean being 3.0 on the visual index for the herbicide-treated plots. The mass of harvested top growth did not differ between mowing treatments (Table 11).

Pelargonic acid applied to mowed or unmowed plots gave strong control of vegetation (mean rating of 7.5) at one week after application (Table 10). The efficacy of this material declined with time after treatment so that, after 5 weeks, control of vegetation was weak (mean rating of 1.8 for both amounts applied). Clove oil (mean rating of 4.0) or limonene (mean rating of 3.8) was less effective than pelargonic acid in management of vegetation at one week following treatment. At 5 weeks after application, the efficacy of clove oil and limonene declined to ratings of 1.0 or less, thereby imparting essentially no suppression of weeds. Application of higher amounts of clove oil or pelargonic acid appeared to increase the short-term (1 week) efficacy of treatments, but this effect was not evident after 5 weeks. The higher amount of limonene was less effective than the lower amount at some dates (Table 10). The higher concentration was too viscous for successful 
TABLE 9: Main effects of herbicide treatments on end-of-season weed mass and visual index rating of annual and perennial vegetation (Field Experiment 2).

\begin{tabular}{lcccc}
\hline \multirow{2}{*}{ Treatment } & \multicolumn{2}{c}{ Weed mass, $\mathrm{g} \mathrm{m}^{-2^{\dagger}}$} & \multicolumn{2}{c}{ Visual index rating } \\
& Annual & Perennial & Annual & Perennial \\
\hline Clove oil & 1,299 & 661 & 0.3 & 1.0 \\
Pelargonic acid & 948 & 380 & 1.1 & 1.4 \\
Citric-acetic acid & 1,263 & 682 & 1.0 & 1.2 \\
Citric acid & 1,898 & 722 & 0 & 0.6 \\
Flaming & 550 & 269 & 0 & 0 \\
Untreated & 2,910 & 1,174 & 0 & 0 \\
LSD $(P=0.05)$ & 270 & 270 & 1.0 & 1.0 \\
\hline
\end{tabular}

${ }^{\dagger}$ Fresh mass on September 28, 2005.

${ }^{\ddagger}$ Visual rating index on September 23, 2005. See Table 3 for indexing scale.

application by spraying. This preparation clogged the nozzle of the sprayer, thereby giving uneven and perhaps inadequate coverage of the plots.

Roadside Experiment 2 (experiment with clove oil, pelargonic acid, limonene, citric-acetic acid, and glyphosate applied to mowed or unmowed plots). Mowing of the plots did not affect the efficacy of the herbicides, as the mean index rating for mowed or unmowed plots was 3.2 for each mowing regime (Table 12). The interaction of mowing with herbicide treatment or with date of observation also was nonsignificant.

In this experiment, the short-term (1 week) efficacy of pelargonic acid by index rating (mean 7.3) was the highest of the alternative herbicides (Table 12). At this time, limonene also gave good control of vegetation with a mean rating of 5.8 , but control with clove oil was weak with a mean rating of 2.6. A mixture of clove oil and limonene (rating of 1.7 at 1 week) was less effective than the herbicides used individually. Perhaps, this effect resulted from uneven application of the viscous mixture of clove oil and limonene. The citric acid formulation at 1 week was rated as 5.0 on the indexing scale. The efficacy of each of the alternative herbicides declined with time over a 5-week period to impart little or no observable control at the end of the growing season. On the other hand, glyphosate gave strong initial control (rating of 7.8 at 1 week) and increased in efficacy with time. The mass of weeds harvested at the end of the season (September 26, 2006) indicated that the treatments with alternative herbicides or with mowing did not differ in season-long control of vegetation (Table 13).

\section{Discussion}

An urgent need exists to develop and implement effective organic-compliant herbicides to meet consumer demand for organic products for farm and highway use $[1,18,19]$. Natural products represent a vast repository of materials and compounds with biological activity, including phytotoxicity [44]. Selected organic acids, such as pelargonic acid, citric acid, and acetic acid, are effective nonselective herbicides for a wide spectrum of annual weed species $[20,44]$. The present study evaluated many organic products derived from plants. Research has shown that concentration used in this study with at least $15 \%$ to $20 \%$ acetic acid provided acceptable weed control of broadleaf annual weeds but gave poor control of annual grasses [11, 14]. Application and timing are critical to maximizing weed control with alternative herbicides [12]. As growth stage advances, control and biomass suppression is decreased, and survival is increased. In the current study and in prior work, a single application was not as effective as multiple applications over the growing season. For example, a single application of pelargonic acid demonstrated immediate or short-term suppression of growth of vegetation; however, the efficacy lasted for no more than 6 weeks, after which regrowth was not distinguishable from untreated vegetation [1]. Also, formulations of citric-acetic acid gave no control or only weak suppression of vegetative growth soon after application, and no suppression was evident after 6 weeks [1]. Repeated applications of alternative herbicides were necessary for season-long efficacy. Two seasons of application were needed for control of stiltgrass (Microstegium vimineum A. Camus) [45].

The effects of flaming lasted for about 6 weeks, similar to the effects of alternative herbicides in the current study and in prior work [1]. Flaming, however, appeared to improve the efficacy of applications of corn gluten meal and mulches. Other research showed that corn gluten meal or flaming used individually was not an effective herbicide in strawberry (Fragaria $\times$ ananassa Duchesne) production [46]. No suppression of growth of roadside vegetation occurred with the use of corn gluten meal, which acted as a nitrogen fertilizer to promote growth [1]. Strawberry yield in plots receiving corn gluten hydrolysate as a fertilizer increased in one year but did not show an increase in another two years of research [9]. Even when used in combination with cultivation, corn gluten meal or clove oil was ineffective and offered little potential in a weed management system for organic peanut (Arachis hypogaea L.) production [47].

In this study, mulches of bark or woodchips were equally effective in imparting strongly suppressive against emerging vegetation for 2 years but were more effective in the first year than in the second year after application. Law et al. [42] reported that no treatment with mulches or corn gluten mean provided acceptable season-long weed control and resulted in low yields of pepper (Capsicum spp. L.). If treatment applications were delayed for 6 weeks, with three shallow cultivations which were used to reduce early weed competition before mulching, average weed control rating provided by the mulches ranged from $45 \%$ to $86 \%$ and resulted in greatly improved yields [42]. Previous reports noted that the costs of materials and labor for the alternative practices, especially mulching, were substantially more than for the conventional herbicides used in this study $[1,19]$. Costs of materials alone for natural products were two to ten times the cost of glufosinate ammonium and six to thirty times the cost of glyphosate. Pelargonic acid was the most economical alternative herbicide with materials costing about three times that of glufosinate ammonium and six times the cost of glyphosate. Cost of mulch was about 200 times the cost of glyphosate. Young [48] reported that, for control of annual 
TABLE 10: Assessment of control of vegetation by alternative herbicides applied at two concentrations to mowed or unmowed plots in roadside research (Roadside Experiment 1).

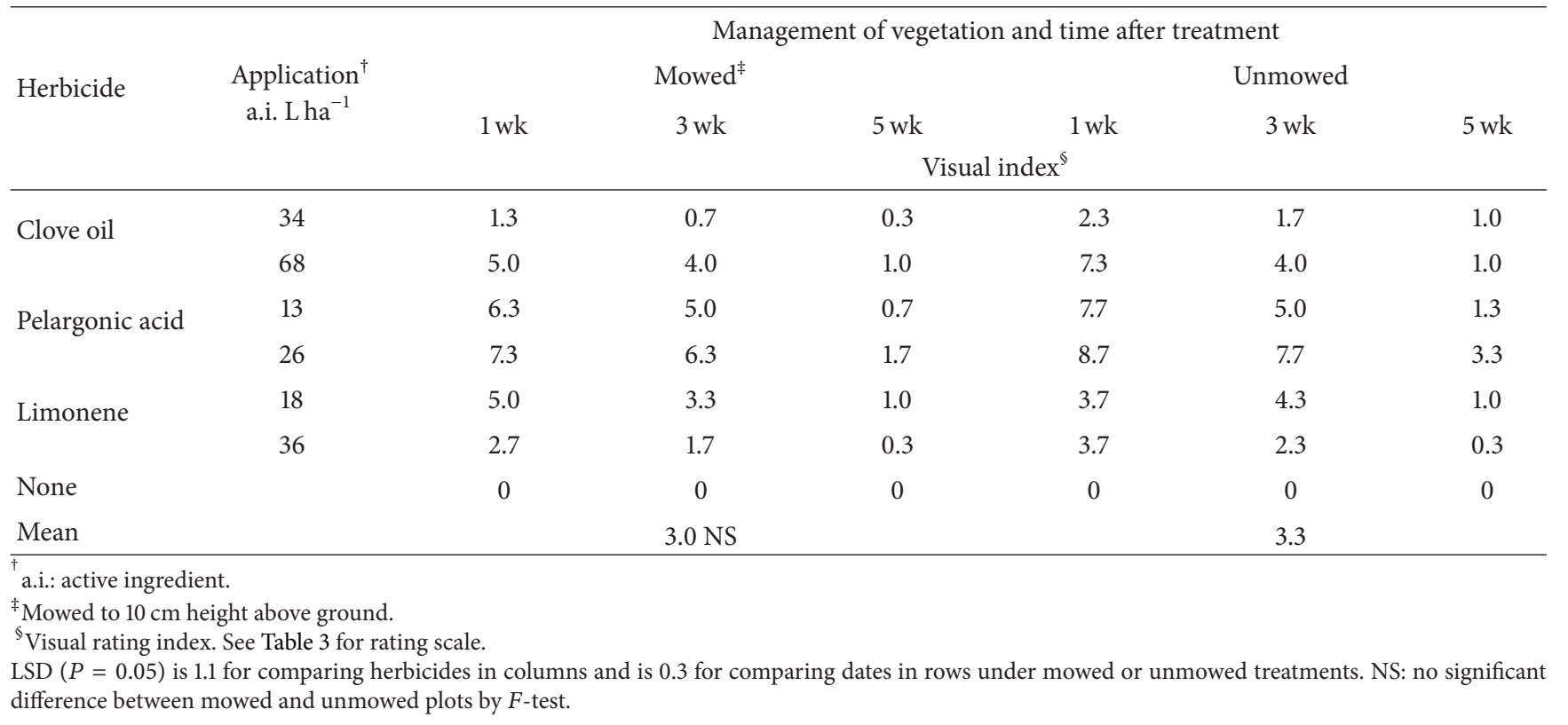

TABLE 11: Mass of vegetation harvested from roadside plots treated with alternative herbicides or with mowing (Roadside Experiment 1).

\begin{tabular}{lccr}
\hline Herbicide & $\begin{array}{c}\text { Application } \\
\text { a.i. } \text { ha }^{-1}\end{array}$ & \multicolumn{2}{c}{ Mass of vegetation, g fresh wt m $^{-2}$} \\
Unmowed \\
Clove oil & 34 & 1,163 & 1,210 \\
& 68 & 1,156 & 1,120 \\
Pelargonic acid & 13 & 1,116 & 1,340 \\
& 26 & 1,273 & 1,180 \\
Limonene & 18 & 1,172 & 1,035 \\
None & 36 & 1,150 & 1,250 \\
Mean & & 1,487 & 1,126 \\
\hline
\end{tabular}

${ }^{\dagger}$ a.i.: active ingredient.

${ }^{\ddagger}$ Mowed to $10 \mathrm{~cm}$ height above ground.

Neither herbicide treatment, mowing, nor their interaction had a significant effect on mass by $F$-test $(P>0.05)$.

vegetation compared to glyphosate, a single application of acetic acid was $79 \%$ as effective and pine oil was $40 \%$ or less as effective. Essential oils from plants were about $80 \%$ as effective as glyphosate. Generally, multiple applications of natural products were needed to attain relative efficacy of $80 \%$ compared to glyphosate. The cost of one or more applications of natural products was more than ten times the cost of one or two applications of glyphosate [48]. Economics may not always be the limiting factor in the use of natural products for pest control in agriculture.

Concerns over the potential impact of pesticides on the environment and stringent pesticide registration procedures are growing. New regulations have reduced the number of synthetic pesticides available in agriculture, and reliance on these pesticides needs to be considered [49]. Dayan et al. $[49,50]$ reviewed the use of pesticides derived from natural products and noted their current applications and potential for impacts in organic and conventional agriculture. These researchers emphasized the needs for development of pesticides from natural products to meet the requirements for new products especially in weed management. The current and previous work demonstrates that alternative methods can be effective means of weed management at roadside sites and for crops in fields but at high economic costs. Multiple applications of the materials will be necessary for effective season-long weed control. End of season results suggested 
TABLE 12: Assessment of control of vegetation by alternative herbicides and a conventional herbicide applied to mowed or unmowed roadside plots (Roadside Experiment 2).

\begin{tabular}{|c|c|c|c|c|c|c|c|}
\hline \multirow{4}{*}{ Herbicide } & \multirow{4}{*}{$\begin{array}{l}\text { Application }^{\dagger} \\
\text { a.i. } \mathrm{L} \mathrm{ha}^{-1}\end{array}$} & \multicolumn{6}{|c|}{ Management of vegetation and time after treatment } \\
\hline & & \multicolumn{3}{|c|}{ Mowed } & \multicolumn{3}{|c|}{ Unmowed } \\
\hline & & $1 \mathrm{wk}$ & $3 \mathrm{wk}$ & $5 \mathrm{wk}$ & $1 \mathrm{wk}$ & $3 \mathrm{wk}$ & $5 \mathrm{wk}$ \\
\hline & & \multicolumn{6}{|c|}{ Visual index ${ }^{\S}$} \\
\hline Clove oil & 34 & 2.3 & 0.7 & 0 & 3.0 & 0.7 & 0 \\
\hline Pelargonic acid & 13 & 6.3 & 3.3 & 1.3 & 8.3 & 4.7 & 1.3 \\
\hline Limonene & 18 & 6.0 & 3.3 & 1.3 & 5.7 & 3.7 & 1.0 \\
\hline Clove oil and & 34 & 1.7 & 0.3 & 0 & 1.7 & 2.3 & 1.0 \\
\hline limonene & 18 & & & & & & \\
\hline Citric acid- & 25 & 5.7 & 1.7 & 0.3 & 4.3 & 1.3 & 0.3 \\
\hline acetic acid & 19 & & & & & & \\
\hline Glyphosate & 2.8 & 8.3 & 9.8 & 10.0 & 7.3 & 10.0 & 10.0 \\
\hline None & & 0 & 0 & 0 & 0 & 0 & 0 \\
\hline
\end{tabular}

${ }^{\dagger}$ a.i.: active ingredient.

${ }^{\ddagger}$ Mowed to $10 \mathrm{~cm}$ height above ground.

${ }^{\S}$ Visual rating index. See Table 3 for indexing scale.

$\operatorname{LSD}(P=0.05)$ is 1.4 for comparing herbicides in columns and is 0.7 for comparing dates in rows under mowed or unmowed treatments.

TABLE 13: Mass of vegetation harvested from plots treated with alternative herbicides or a conventional herbicide applied to mowed or unmowed roadside plots (Roadside Experiment 2).

\begin{tabular}{lccc}
\hline Herbicide & $\begin{array}{c}\text { Application } \\
\text { a.i. } \text { L ha }^{-1}\end{array}$ & \multicolumn{2}{c}{ Mass of vegetation, $\mathrm{g}$ fresh wt m $^{-2}$} \\
Unmowed
\end{tabular}

${ }^{\dagger}$ a.i.: active ingredient.

${ }^{\ddagger}$ Mowed to $10 \mathrm{~cm}$ height above ground.

Except for the effect of glyphosate, which differed from all other treatments, neither herbicide treatment or mowing nor their interaction had a significant effect on mass $(P>0.05)$. LSD $(P=0.05)=350$ for the interaction. Mowing and not mowing did not differ by $F$-test, $P>0.05$.

that no second-season control except for mulching would be imparted.

\section{Conflict of Interests}

The authors declare that there is no conflict of interests regarding the publication of this paper.

\section{Acknowledgment}

This research was supported in part by the Massachusetts Department of Transportation-Highway Division, Boston, Massachusetts.

\section{References}

[1] A. V. Barker and R. G. Prostak, "Herbicides alternatives research," Final Report, Massachusetts Highway Department, Boston, Mass, USA, 2008.

[2] K. Owens, "The right way to vegetation management," Pesticides and You, vol. 19, no. 1, pp. 9-17, 1999.

[3] S. O. Duke, "Natural pesticides from plants," in Advances in New Crops, J. Janick and J. E. Simon, Eds., pp. 511-517, Timber Press, Portland, Ore, USA, 1990.

[4] T. Tworkoski, "Herbicide effects of essential oils," Weed Science, vol. 50, no. 4, pp. 425-431, 2002.

[5] N. E. Christians, "Use of corn gluten meal as a natural preemergent weed control," Turfgrass Trends, vol. 11, no. 1, pp. t14t16, 2002. 
[6] D. L. Y. Liu and N. E. Christians, "Isolation and identification of root-inhibiting compounds from corn gluten hydrolysate," Journal of Plant Growth Regulation, vol. 13, no. 4, pp. 227-230, 1994.

[7] D. L. Liu and N. E. Christians, "Bioactivity of a pentapeptide isolated from corn gluten hydrolysate on Lolium perenne L.," Journal of Plant Growth Regulation, vol. 15, no. 1, pp. 13-17, 1996.

[8] C. L. Webber, J. W. Shrefler, and M. J. Taylor, "Influence of corn gluten meal on squash plant survival and yields," HortTechnology, vol. 19, no. 2, pp. 346-352, 2010.

[9] C. A. Dilley, G. R. Nonnecke, and N. E. Christians, "Corn-based extracts to manage weeds and provide nitrogen in matted-row strawberry culture," HortScience, vol. 37, no. 7, pp. 1053-1056, 2002.

[10] F. Forcella, T. James, and A. Rahman, "Post-emergence weed control through abrasion with an approved organic fertilizer," Renewable Agriculture and Food Systems, vol. 26, no. 1, pp. 3137, 2011.

[11] D. C. Brainard, W. S. Curran, R. R. Bellinder et al., “Temperature and relative humidity affect weed response to vinegar and clove oil," Weed Technology, vol. 27, no. 1, pp. 156-164, 2013.

[12] G. J. Evans, R. R. Bellinder, and M. C. Goffinet, "Herbicidal effects of vinegar and a clove oil product on redroot pigweed (amaranthus retroflexus) and velvetleaf (abutilon theophrasti)," Weed Technology, vol. 23, no. 2, pp. 292-299, 2009.

[13] G. J. Evans, R. R. Bellinder, and R. R. Hahn, "Integration of vinegar for in-row weed control in transplanted bell pepper and broccoli," Weed Technology, vol. 25, no. 3, pp. 459-465, 2011.

[14] J. A. Ivany, "Acetic acid for weed control in potato (Solanum tuberosum L.)," Canadian Journal of Plant Science, vol. 90, no. 4, pp. 537-542, 2010.

[15] E. Johnson, T. Wolf, B. Caldwell, R. Barbour, R. Holm, and K. Sapsford, "Efficacy of vinegar (acetic acid) as an organic herbicide. ADF Project no. 20020202 and AAFC Project A03637," Final Report, University of Saskatchewan, Saskatoon, Canada, 2004.

[16] J. Radhakrishnan, J. Teasdale, and C. Coffman, "Agricultural applications of vinegar," Proceedings of Northeastern Weed Science Society, vol. 57, pp. 63-64, 2003.

[17] C. L. Webber III and J. W. Shrefler, "Organic weed control with vinegar: application volumes and adjuvants," Proceedings of Horticultural Industry Show, vol. 26, pp. 149-151, 2007.

[18] H. F. H. Abouziena, A. A. M. Omar, S. D. Sharma, and M. Singh, "Efficacy comparison of some new natural-product herbicides for weed control at two growth stages," Weed Technology, vol. 23, no. 3, pp. 431-437, 2009.

[19] A. V. Barker and R. G. Prostak, "Alternative management of roadside vegetation," HortTechnology, vol. 19, no. 2, pp. 346-352, 2009.

[20] R. Coleman and D. Penner, "Desiccant activity of short chain fatty acids," Weed Technology, vol. 20, no. 2, pp. 410-415, 2006.

[21] M. Windholz, Ed., The Merck Index, Merck \& Co, Rahway, NJ, USA, 1983.

[22] A. O. Ayeni, B. A. Majek, J. R. Johnson, and R. G. Obal, "Container nursery weed control: Bittercress, groundsel, and oxalis," Rutgers Coop. Ext. Fact Sheet 939.

[23] J. E. Arboleya, J. G. Masabni, M. G. Particka, and B. H. Zandstra, "Identification of preharvesr desiccants for use in onion production," HortTechnology, vol. 15, no. 4, pp. 808-811, 2005.
[24] S. L. F. Meyer, D. K. Lakshman, I. A. Zasada, B. T. Vinyard, and D. J. Chitwood, "Dose-response effects of clove oil from Syzygium aromaticum on the root-knot nematode Meloidogyne incognita," Pest Management Science, vol. 64, no. 3, pp. 223 229, 2008.

[25] Y. C. Yang, H. S. Lee, J. M. Clark, and U. J. Ahn, "Insecticidal activity of plant essential oils against Pediculus humanus capitis (Anoplura: Pediculidae)," Journal of Medical Entomology, vol. 41, no. 4, pp. 699-704, 2004.

[26] G. K. Kishore, S. Pande, and S. Harish, "Evaluation of essential oils and their components for broad-spectrum antifungal activity and control of late leaf spot and crown rot diseases in peanut," Plant Disease Journal, vol. 91, no. 4, pp. 375-379, 2007.

[27] G. C. Lucas, E. Alves, R. B. Pereira, A. B. Zacaroni, F. J. Perina, and R. M. de Souza, "Indan clove essential oil in the control to tomato bacterial spot," Journal of Plant Pathology, vol. 94, no. 1, pp. 45-51, 2012.

[28] J. M. van der Wolf, Y. Birnbaum, P. S. van der Zouwen, and S. P. C. Groot, "Disinfection of vegetable seed by treatment with essential oils, organic acids and plant extracts," Seed Science and Technology, vol. 36, no. 1, pp. 76-88, 2008.

[29] N. S. Boyd and E. B. Brennan, "Burning nettle, common purslane, and rye response to a clove oil herbicide," Weed Technology, vol. 20, no. 3, pp. 646-650, 2006.

[30] A. Stokłosa, R. Matraszek, M. B. Isman, and M. K. Upadhyaya, "Phytotoxic activity of clove oil, its constituents, and its modification by light intensity in broccoli and common lambsquarters (Chenopodium album)," Weed Science, vol. 60, no. 4, pp. 607-611, 2012.

[31] R. Di Pasqua, G. Betts, N. Hoskins, M. Edwards, D. Ercolini, and G. Mauriello, "Membrane toxicity of antimicrobial compounds from essential oils," Journal of Agricultural and Food Chemistry, vol. 55, no. 12, pp. 4863-4870, 2007.

[32] G. Gupta and V. A. Krischik, "Professional and consumer insecticides for management of adult Japanese beetle on hybrid tea rose," Journal of Economic Entomology, vol. 100, no. 3, pp. 830-837, 2007.

[33] R. G. Hollingsworth, "Limonene, a citrus extract, for control of mealybugs and scale insects," Journal of Economic Entomology, vol. 98, no. 3, pp. 772-779, 2005.

[34] I. Park, L. Kim, I. Choi, Y. Lee, and S. Shin, "Fumigant activity of plant essential oils and components from Schizonepeta tenuifolia against Lycoriella ingenua (Diptera: Sciaridae)," Journal of Economic Entomology, vol. 99, no. 5, pp. 1717-1721, 2006.

[35] I. Rasooli and M. B. Rezaei, "Bioactivity and chemical properties of essential oils from Zataria multiflora Boiss and Mentha longifolia (L.) Huds.," Journal of Essential Oil Research, vol. 14, no. 2, pp. 141-146, 2002.

[36] M. A. Ibrahim, E. J. Oksanen, and J. K. Holopainen, "Effects of limonene on the growth and physiology of cabbage (Brassica oleracea L) and carrot (Daucus carota L) plants," Journal of the Science of Food and Agriculture, vol. 84, no. 11, pp. 1319-1326, 2004.

[37] J. Ascard, "Dose-response models for flame weeding in relation to plant size and density," Weed Research, vol. 34, no. 5, pp. 377385, 1994.

[38] J. Ascard, "Effects of flame weeding on weed species at different developmental stages," Weed Research, vol. 35, no. 5, pp. 397-411, 1995.

[39] M. N. Rifai, T. Astatkie, M. Lacko-Bartosova, and J. Gadus, "Effect of two different thermal units and three types of 
mulch on weeds in apple orchards," Journal of Environmental Engineering and Science, vol. 1, no. 5, pp. 331-338, 2002.

[40] A. V. Barker and P. C. Bhowmik, "Weed control with crop residues in vegetable cropping systems," Journal of Crop Production, vol. 4, no. 2, pp. 163-183, 2001.

[41] A. V. Barker and T. A. O'Brien, "Weed control in establishment of wildflower sods and meadows," Proceedings of the NorthEastern Weed Science Society, vol. 49, pp. 56-60, 1995.

[42] D. M. Law, A. B. Rowell, J. C. Snyder, and M. A. Williams, "Weed control efficacy of organic mulches in two organically managed bell pepper production systems," HortTechnology, vol. 16, no. 2, pp. 225-232, 2006.

[43] R. G. D. Steel and J. A. Torrie, Principles and Procedures of Statistics, McGraw Hill, New York, NY, USA, 2nd edition, 1980.

[44] S. O. Duke, F. E. Dayan, A. M. Rimando et al., "Chemicals from nature for weed management," Weed Science, vol. 50, no. 2, pp. 138-151, 2002.

[45] J. S. Ward and T. L. Mervosh, "Nonchemical and herbicide treatments for management of Japanese stiltgrass (Microstegium vimineum)," Invasive Plant Science and Management, vol. 5, no. 1, pp. 9-19, 2012.

[46] T. W. Miller, C. R. Libbey, and B. G. Maupin, "Evaluation of organic amendments and flaming for weed control in mattedrow strawberry," HortScience, vol. 48, no. 3, pp. 304-310, 2013.

[47] W. C. Johnson III, M. A. Boudreau, and J. W. Davis, "Combinations of corn gluten meal, clove oil, and sweep cultivation are ineffective for weed control in organic peanut production," Weed Technology, vol. 27, no. 2, pp. 417-421, 2013.

[48] S. L. Young, "Natural product herbicides for control of annual vegetation along roadsides," Weed Technology, vol. 18, no. 3, pp. 580-587, 2004.

[49] F. E. Dayan, C. L. Cantrell, and S. O. Duke, "Natural products in crop protection," Bioorganic and Medicinal Chemistry, vol. 17, no. 12, pp. 4022-4034, 2009.

[50] F. E. Dayan, D. K. Owens, and S. O. Duke, "Rationale for a natural products approach to herbicide discovery," Pest Management Science, vol. 68, no. 4, pp. 519-528, 2012. 


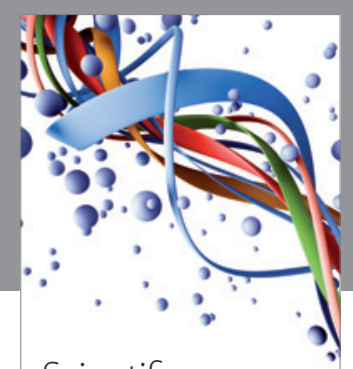

Scientifica
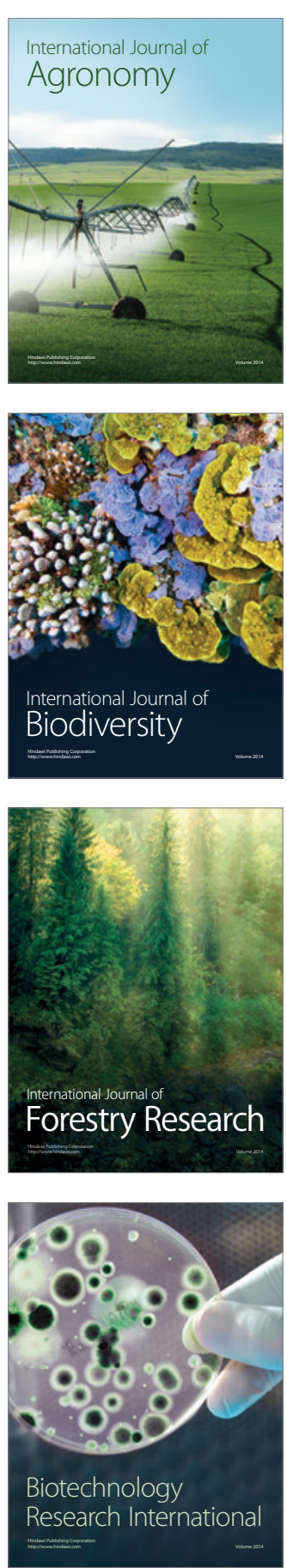
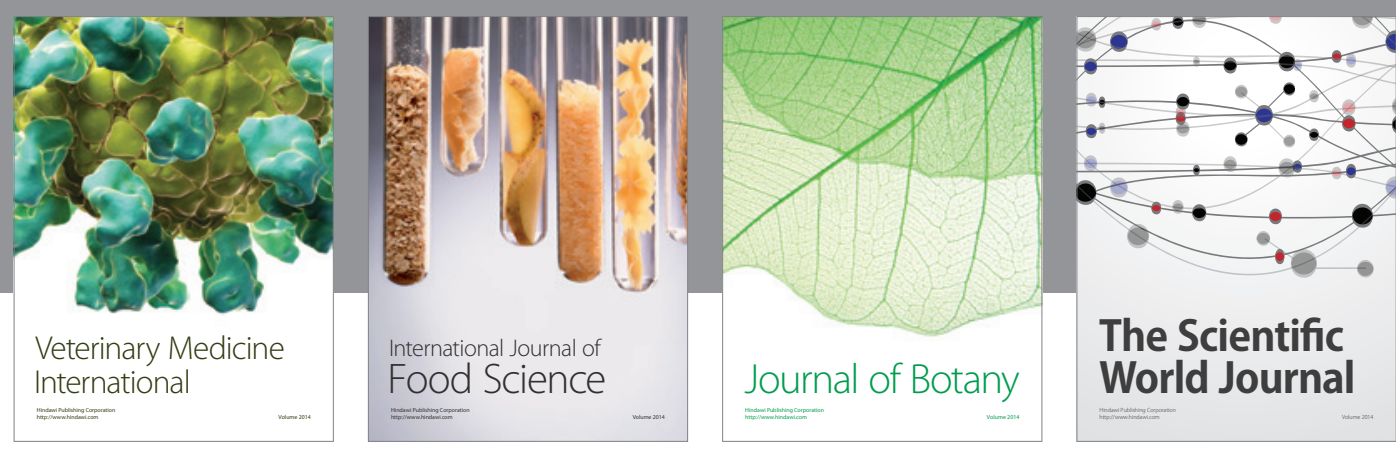

The Scientific World Journal
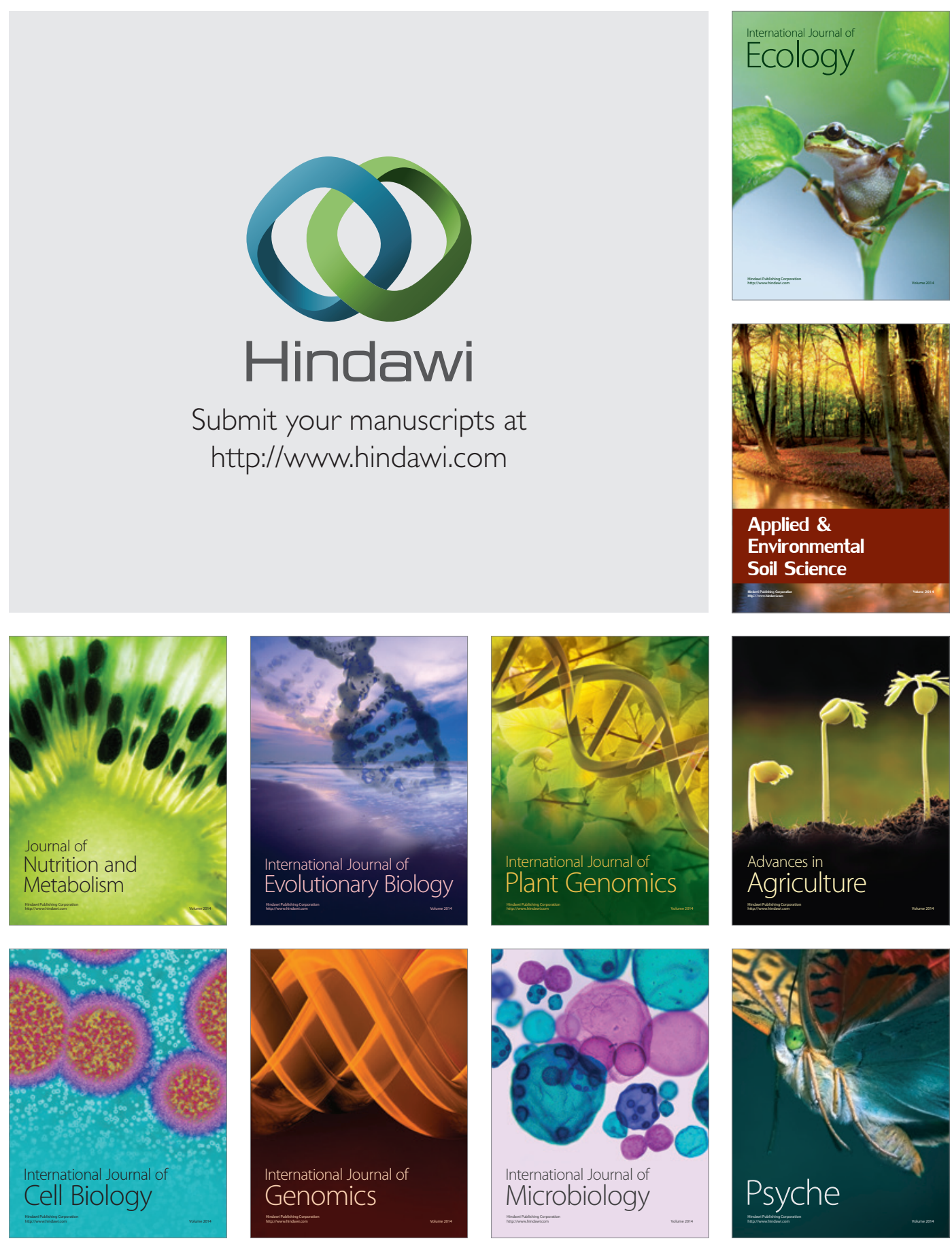